\title{
The Study on Legal Issues Concerning China's Tourism Environmental Protection
}

\author{
Jian-gang Quan ${ }^{1, a}$ and Zhi-guo Zhang ${ }^{2, b}$ \\ ${ }^{1}$ Law School, Renmin University of China, Beijing, 100872, China; \\ Teaching Affairs Division, Hainan Vocational College of Political Science and Law, Haikou, Hainan, \\ 571100, China \\ ${ }^{2}$ Research Department, Hainan Vocational College of Political Science and Law, Haikou, Hainan, \\ 571100, China \\ aquanjiangang@126.com, bhjxzzg@126.com
}

\section{Keywords: Tourism Environment,Sustainable Development of Tourism,Ecological Enviromenment Ethics, Environment Protection}

\begin{abstract}
With the development of tourism, the contradiction between tourists and environment is becoming more and more serious, which is mainly reflected in the rapid development of tourism industry and the lack of legislation on tourism environmental protection. China's current laws and regulations exist in the absence of the basic law of tourism environment protection, there has no formation of tourism environment protection law system, the tourism environment protection legislation is too principle, feasibility is poor and so on. In the process of building the legal system of tourism environmental protection, we need to sort out the property in relation to which the ownership or the right of use is unknown or disputed, strengthen out the management system, adopt the basic framework of the tourism environmental protection law, and improve the basic content of the tourism environmental protection law. At the same time, enact the tourism environmental protection law, strengthen the concept of traditional legal department of environmental protection, formulate a more comprehensive tourism environment protection legal system.
\end{abstract}

\section{Introduction}

It has two theories of tourism environment protection in the tourism academic area. The first theory is sustainable development of Tourism. "Sustainable development" is a basic principle of ecological protection law, and it is also a new development idea and development strategy of human society. In terms of its original meaning, sustainable development is not only to meet the development of the contemporary people, but also to satisfy the development of future generations of the threat. The sustainable development of tourism is in full consideration of tourism and natural resources, the mutual influence of the social, cultural and ecological environment premise, the tourism development based on the bearing capacity of ecological environment, strive for tourism and natural resources, human survival environment coordinated development, and for the benefit of future generations of a tourism economic development mode.

Sustainable development requires a natural basis, coordinate with the environmental carrying capacity, and ultimately promote and guide the development of the implementation. Therefore, sustainable development requires people to change their attitude towards nature. According to the island of Lanzarote, Canary Islands, Spain, 27-28 April, 1995 "the sustainable tourism development in the world conference by the sustainable development of tourism charter, the sustainable tourism development is the essence content, that is, which are requirements of tourism and nature, culture and living environment of mankind as a whole, the balance relationship between nature, culture and living environment of human beings to many tourist destinations have their own characteristics, tourism development can not destroy the fragile ecological balance".

The second theory is "ecological environment ethic", which is from the view of environment and development, looking back examining the process of human history, the establishment and 
maintaining of a development model must be accompanied with the formation and evolution of some environmental ethics.

Ecological environmental ethics is closely related to nature, ecology and environment, and it is the ethics of the relationship between human and ecological environment, and it can be said that it is the ethical responsibility of human and natural environment. Ethical connotation includes belief, attitude and value. Environmental ethics is the concept, attitude and value of human environment. When the traditional ethics extends the research object from the interpersonal ethics to the moral relationship between man and nature, the ecological ethics is also produced. Ecological ethics, which advocates the extension of moral relations to all kinds of non-human beings, tries to use morality to restrain the behaviour of human being. Therefore, ecological environmental ethics concept can be summarized as follows: ecological ethics is embodied in human life and production activities in the process of a series of protection of the ecological environment and natural resources of rational thinking and moral norms. It is the study of the theory of moral issues related to ecological environmental protection, which aims to provide an appropriate basis for the protection of the ecological environment and norms.

\section{The Legislation Status of China's Tourism Environmental Protection}

The Constitution. The constitution has the highest effect on the protection of resources and environment. Article 26 of the Constitution stipulates: "the state protects and improves the environment in which people live and the ecological environment, it prevents and controls pollution and other public hazards". The second clause of article 9 stipulates: "the state ensures the rational use of natural resources and protects rare animals and plants. Appropriation or damaging of natural resources by any organization or individual by whatever means is prohibited, the second clause of the article 22 : "the state protects site of scenic and historical interest, valuable cultural monuments and relics and other significant items of China's historical and cultural heritage". The constitution of these Provisions, emphasizes on natural resources to strict protection and rational use, to prevent unreasonable exploitation of natural resources and cause environmental damage, environmental protection activities in China Tourism and tourism environment protection legislation provides guiding principles and legislative basis.

Laws. Tourism Law of the People's Republic of China is the first tourism basic law adopted at the 2nd Meeting of the Standing Committee of the Twelfth National People's Congress on April 25, 2013. Article 19: The tourism development plan shall be compatible with the overall plan for land utilization, the urban and rural development plan, the environmental protection plan and other plans for protection and utilization of natural resources and cultural resources such as historical relics.

Administrative regulations. Tourism administration laws and regulations are one of the main forms of tourism environmental protection law, the various administrative regulations of tourism environment protection, to a certain extent, make up the deficiency of the legislation of the state legislature. Mainly refers to the "Regulations" or the "Provisional Regulations", such as "the people's Republic of China for the conservation of nature area Ordinance, 1985, the State Council promulgated the "Scenic Area Management Provisional Regulations", in the scenic area of the division standard, management system, planning, prohibition and restriction of regulations, penalties and other aspects made a series of regulations.

Local regulations. The local legislature of the province with rich tourism resources and the more developed tourism industry combined with the specific circumstances of the local authorities have made some local regulations. Mainly in the form of regulations, such as the " the Guangxi Zhuang Autonomous Region Tourism Management Regulations", "Sichuan Tourism Management Regulations", "Yunnan Tourism Management Regulations", "Hainan Tourism Management Regulations" and so on. These local regulations combined with local characteristics, to provide more detail and clear guidance for the local tourism environmental protection work, so that the tourism environmental protection law is more operational. 
Local tourism regulations is mainly refers to the government issued by the management measures, regulations, implementation details, and notification, such as Hunan Province " the Yuelu Mountain scenic area management regulations", Sichuan Province "the scenic area management regulations", Yunnan Province "the Dianchi Lake in Kunming International Tourism degree Resort Management approach", and so on. Most of these local regulations for a type of tourism resources or a specific tourist area to develop management regulations or measures in the actual operation is very effective.

\section{Legislation Issues on China's Tourism Environment Protection}

The current legal mechanism on tourism environmental protection provisions formulated the tourism industry and environmental protection scope and principles, it has made the strict responsibilities for violating the compulsory provisions of the laws and administrative regulations, at the same time, the competent department of tourism environment is multiple. However, it should be noted that these scattered regulations also caused a series of legal issues of China's ecological tourism environmental protection work.

First, the relationship of property rights are unclear, in a sense, the management system is disorder.

China's tourism resources property is not clear, the excessive exploitation of tourism resources

results in a weak environment protection. It has two main reasons for unclear property rights: one is the ownership and management rights are unclear, literally it means they have property, but actually its management right is inoperative, the economic relations between the central and local governments as well as between various stakeholders lack of clearly defined, that a subject cannot effectively perform exclusive rights, leading to an inefficient allocation of resources. Due to the problem of property rights of tourism resources there has no clear legal definition, resulting in the management system of tourism resources in our country has serious drawbacks, China's tourism environmental protection work smoothly cause direct negative impacts.

Multiple management mechanism also caused tourism resources have not been effectively protected, unclear responsibility and right and profit caused decentralization, departmental interests, local interests, resulting in tourism resources cannot be unified planning, unified development, unified protection and the tourism management is not unified. Legal norms on the management system of the ecological tourism environmental protection management system caused by the defects of the management of the weak.

Secondly, the lack of environmental protection of the tourism environment, the basic law, there is no form of eco-tourism environmental protection law system.

Although our country made a tourism related laws and regulations, but most of them made by various interested departments according to the needs of departments and different objects of protection of their own, more scattered, lack of system and integrity, for the same resource and several regulations, in the use of the law it is difficult to make a choice, resulting in legislation between repeated and even contradictory.

The existing legislation of tourism environment protection has the characteristics of low legislative level, department and local legislation. The law resulting from the lack of authority produce the phenomenon of non-compliance and lax enforcement of the law, on the one hand, the legislative level is not high, lack of overall consideration, departmental protectionism, local protectionism prevailed even problems.

To solve the dilemma of existing legislation, it is necessary to develop a national tourism resources development, utilization, protection with demonstrative and guiding role of the tourism environmental protection fundamental law.

Third, the legal provisions are too principles and lack of feasibility.

Existing tourism environmental protection law on environmental protection methods and means for the provisions in principle, but the provisions in the protection and management of the program, national and local and departmental responsibilities and relationships, protection fund sources and 
violation penalties are too general, lack of the specific terms of the operation, lead to the practice of the arbitrary discretion. In most of the regulatory documents, there is no clear tourism and management of environmental protection departments, in final, the local environmental protection departments has no authority and power to handle with the environmental protection in tourism.

\section{Legislation Conception on China's Tourism Environment Protection}

First, Establishing the Basic Principles of Ecological Protection Law. The basic principle of Ecological Protection Law refers to the basic or main criterion to adjust the relationship between human and resource environment in the development process of ecological tourism. Compared with the basic system, it does not set the specific facts of the state, but it is the guiding principle and the starting point of guiding the ecological tourism environmental management activities. The basic principles of ecological protection law should include: the principle of priority of ecological protection and the principle of coordinated development of general environmental protection are different. The priority principle emphasizes that in the contradiction between resource protection and economic development, the economic benefit should be abandoned, and the protection of resources should be given priority. The principle of ecological balance maintenance should pay special attention to the ecological balance in the process of developing eco-tourism. This requires appropriate development of eco-tourism resources, scientific management of eco-tourism environment, and strict monitoring, to ensure that the norms of the main acts. Other principles of eco tourism environmental protection, in addition, the damage to the environment, the principle of paying for the environment, the public participation

And principles are equally applicable to ecological tourism and environmental protection field, but in the ecological tourism and environmental protection legislation deal with the to be adjusted and improved to more for the guidance of ecological tourism environmental protection work. For example, ecological tourism and environmental protection of the problem of insufficient funds, tourism and business activities increased burden of ecological and environmental protection work, need more funds for environmental governance, rely on the government fiscal expenditure has been far can not meet the needs of environmental problems. In the tourism activities which enjoy the economic benefits of the tourism industry. Therefore, in the protection of the ecological tourism environment, we should establish the basic principle of "who pays", so that the pursuit of economic benefits and the protection of the ecological tourism environment are unified. Also, as the public participation in the problem, eco-tourism activities in general do not directly bear the consequences of environmental damage; the local residents are the real victims. Which need to launch eco-tourism area residents to participate in ecological tourism and environmental protection work, it has been gradually established ecological tourism area residents to participate in the system is carrying out the public participation principle of good form should be recognized in the legislation.

\section{Second, Establishing The Basic System of Ecological Protection.}

The System of Qualify and Authentication of Ecological Tourism. It is to ensure the quality of environmental protection of ecological tourism developers, and establish a strict industry access mechanism, develop a suitable ecological tourism certification standard and standardize the corresponding certification system.

The system of ecological protection education. The ecological protection law should stipulate the system of environmental education, and enforce the education of ecological environment. Environmental education is the basic feature of ecological tourism, ecological tourism environmental education includes four aspects: nature and cultural knowledge, ecological environmental awareness (including environmental value concept of participation and protection of ecological environment behavior is the degree of consciousness), guide of ecological tourism, ecological tourism's behavior.

Strict liability. The existing law lacks corresponding liability clauses, it has not designed corresponding penalties system, which makes legal deterrence, is greatly reduced, in fact, and it 
shows a failure to abide by the law. The purpose of ecological protection law is to deal with the ecological environment protection of the subject of rights, obligations and related legal liability, the future law and judicial interpretation is to make corresponding provisions and the corresponding penalties as a guarantee.

Strictly enforcing the Tourism Environment Protection Law. Strictly enforcing the law is an important measure to protect tourism environment. At present, tourism laws and regulations of environmental protection in China has not been well implemented. Some serious acts on violations of the laws and regulations of tourism environmental protection have been happened often, which need to be investigated, for escaping law, some people have through various improper means to evade their responsibilities, some law enforcement agencies are making unwholesome tendencies and law enforcement to further increase the difficulty, so that offenders have not been punished, those act damaged the authority of the law seriously. The offender will bear some legal responsibility and legal sanctions, so as to it made the public feel deeply that the law of tourism environmental protection which is also the enforceable law.

\section{Conclusions}

Therefore, it's very important and imperative to advocate and implement a sustainable development in eco-tourism. This paper analyzes environmental protection laws and system of eco-tourism, it finds out that there are many deficiencies and gaps in legislation, law enforcement and justice, and the laws are uncoordinated with the eco-tourism hot. So, we need further research and exploration to solve this problem.

\section{Acknowledgments}

This work was financially supported by the fund project of Education Department of Hainan Province (Hnjg2015-93).

\section{References}

[1]W.Z.ZHOU; J.Y.MA; S.W.ZHAO and S.J. MENG: Design Responsibility Based on Tourism Ethics: A Study of the Planning and Design of Xijin National Wetland Park in Guangxi. Journal of Shanghai Jiaotong University, 2015, 49(11).

[2]L.X.KONG: Overall Protection Mechanisms of Tourist Safety in Tourism Law. Chinese Journal of Tourism Tribune, 2013, 28(8): 29-30.

[3]National People's Congress. China Tourism Law, China Tourism News, 2013-04-26.

[4]Y.J. SHI: Thought of Tourism Environmental Protection Law Issues, Master Degree Thesis, CNKI website, 2013,3,28.

[5]J.P. LI: On Accelerating the Perfection of the System of Tourism Public Service. Chinese Journal of Tourism Tribune, 2012, 27(1):4.

[6]S.Y. XIA; B. DAI: On Operational Characters and Policy Orientation in China's Development Stage of Mass Tourism. Chinese Journal of Tourism Tribune, 2009, 24(13):13-17.

[7]Y. SU: A Study on Beijing's Tourism Public Services: Beijing Tourism Administration. Researches on the Development of Beijing's Tourism Industry (2008). Beijing: China Travel \& Tourism Press, 2009. P157-181.

[8]Norman G. Cournoyer, Anthony G, Marchall, Karen L. Morris: Hotel, Restaurant and Travel Law, A Preventive Approach, Seventh Edition, Delmar Cengage Learning, 2008.

[9]Alexander Anolik, Esp. Travel, Tourism, and Hospitality Law, Second Edition, 1995. ISBN: 0-935920-60-9. 
[10]Alexander Anolik, Esq. The Law and the Travel Industry, Third Edition, 1990, Printed in San Francisco, California. ISBN: 0-931290-94-5. 